\title{
Avoiding the manufacture of 'sameness': first-in-family students, cultural capital and the higher education environment
}

\author{
Sarah O'Shea ${ }^{1}$
}

Published online: 16 September 2015

(C) Springer Science+Business Media Dordrecht 2015

\begin{abstract}
Drawing upon Bourdieu's theories of social and cultural capital, a number of studies of the higher education environment have indicated that students who are first-infamily to come to university may lack the necessary capitals to enact success. To address this issue, university transition strategies often have the primary objective of 'filling students up' with legitimate forms of cultural capital required by the institution. However, this article argues that such an approach is fundamentally flawed, as students can be either framed as deficit or replete in capitals depending on how their particular background and capabilities are perceived. Drawing on interviews conducted with first-in-family students, this article explores how one cohort considered their movement into university and how they enacted success within this environment. Utilising Yosso's Community Cultural Wealth framework, this article discusses how these individuals drew upon existing and established capital reserves in this transition to higher education.
\end{abstract}

Keywords First-in-family students · Cultural capital - Community Cultural Wealth · Transition to higher education

\section{Introduction}

The impetus for this study was derived from an interest in how first-in-family (or first generation) students manage the transition into the higher education environment. Literature around first-in-family students has largely portrayed this cohort in deficit terms using words such as 'challenges', 'difficulties' and 'help' (Brachman 2012; Gardner 1996; Thayer 2000). Research has problematised this group as somehow lacking compared to

Sarah O'Shea

saraho@uow.edu.au

1 Building 67, McKinnon Building, University of Wollongong, Northfields Avenue, Wollongong, Australia 
other higher education students (Spiegler and Bednarek 2013). Addressing gaps in knowledge is often regarded as being the responsibility of educational institutions, who are charged with the task of 'filling up' students with 'forms of cultural knowledge deemed valuable by dominant society' (Yosso 2005, p. 75). Bejarano and Valverde (2012) identify how many universities set about 'manufacturing sameness' in the first year of university, essentially focusing on removing students from familial and social contexts in an attempt to acculturate them into the university.

However, what if first-in-family students' perspectives and experiences of university were discussed from a strengths perspective? Rather than regarding first-in-family status as somehow a lack, it could be assessed in terms of strengths. Yosso's framework has largely been applied to the experience of ethnic minorities returning to education including migrant farmworkers (Bejarano and Valverde 2012) and Native American Women (Waterman and Lindley 2013). Whilst appropriating models that are rooted in cultural contexts needs to be done cautiously and sensitively, this article begins to consider how the concept of cultural wealth might assist in more deeply understanding the experiences of one group of underrepresented and educationally disadvantaged learners in Australia.

Beginning with a review of the literature around first-in-family university participants, the article will then detail the research design and the conceptual underpinnings of this study. The interview data will then be discussed with reference to the Yosso's Community Cultural Wealth framework. It is acknowledged that this is not an unproblematic application, given the cultural situatedness of this framework, but arguably applying alternative lenses to data enables knowledge to be 'proliferated rather than foreclosed and simplified' (Jackson and Mazzei 2013, p. vii). One of the things that this paper contributes is exploring how a strengths based model, such as Yosso's, can enable data to be unpacked in order to re-envisage what is assumed to be a weakness or lack in terms of strengths. Further details about the contextual ramifications of applying this theory to this cohort will also be discussed in this article.

\section{First-in-family students and university}

Globally, one of the student cohorts most likely to depart higher education prior to receiving a degree is those who are first in the family to attend university. Within the USA, this student cohort does not achieve to the same level academically as peers: between 1992 and 2000, $43 \%$ of first-in-family students left university without a degree (Chen 2005), whilst Ishitani (2006) indicates that first-generation students were 8.5 times more likely to drop out of their studies compared to students whose parents had graduated college. Within Australia, $26 \%$ of first-in-family students are reported as considering leaving university in the first year of university study, a figure that increases to $34 \%$ for later year students (Coates and Ransom 2011). Given the high risk of potential attrition, the need to gain a better understanding of how this cohort transitions into and engages with the university sector is required.

Exploring the research and literature on first-in-family students is hampered by two factors: firstly, there are a diversity of definitions associated with this category, and secondly, much of the research does not focus explicitly on first-in-family students but instead reflects upon broader issues related to social class background, access and disadvantage. Whilst the first-in-family cohort is included in these studies, the focus is often not on this group or the impact of parental educational levels on attainment or educational success. 
With this in the mind, this literature review will firstly identify how the term first-in-family is being defined for the purposes of this study before providing an overview of key themes in the related literature.

The most common definition of first-in-family or first-generation status relies on measurements of parental education levels (Spiegler and Bednarek 2013). In the US literature, these educational levels can include attendance at college, whereas other studies refer to family income levels, and in the UK, class affiliation (Spiegler and Bednarek 2013). Such differentials make comparative analysis of first-in-family student numbers difficult across countries. For the purposes of this study, first-in-family status has been defined as no one in the immediate family of origin including siblings or parents having previously attended a university or having completed a university degree.

Pascarella et al. (2004) conducted an early literature review focused on first-in-family students and concluded that three main themes emerge in relation to North American literature. The first theme concerned comparative analyses between first-in-family student and their peers, with research largely concluding that this group is disadvantaged in terms of preparedness and knowledge about higher education, financial support and also expectations around the degree. A second theme in the literature acknowledged that the transition between schools and tertiary institutions tends to be more problematic for firstin-family students, whilst the third referred to higher attrition rates and differences in postgraduation outcomes for this cohort.

More recently, Spiegler and Bednarek (2013) conducted a review of 70 studies conducted in the USA, Germany, UK and Canada. Based on this review, these authors conclude that first-in-family students are generally constructed as a 'group at risk' (p. 329) who has difficulty fitting into the university environment and 'mastering the college role' (p. 330). Spiegler and Bednarek (2013) report that first-in-family students are represented as simply 'coping' and collectively have a lower sense of belonging within the institution. Bryan and Simmons (2009) in their study of Appalachian first-in-family students similarly identify how their participants reflected on numerous obstacles encountered within university. These included difficulties managing relationships with community and family; dealing with the pressure of being the first in the family; managing poverty; and reconciling different identities as well as concerns about returning home after study. However, it is important not to simply position students as problematic and instead recognise the overarching constraints that this cohort may operate within, the next section will explore these issues in more depth.

\section{Educational stratification and first-in-family students}

This article takes as its starting point that education is socially stratified with those from higher strata backgrounds generally accessing and succeeding more than those who are from poorer, disadvantaged sectors of society. The OECD (2013) reports that amongst member countries, students from a more educated family are 'almost twice (1.9)' as likely to attend university (p. 3) than peers. Ball et al. (2002) argue that those families who have generational experience of university, an educational memory, inculcate a belief that university is a predetermined choice and therefore a non-decision. Trajectories related to family, education and also work are each constrained and influenced by both history and social stratification, as Elder (1998) succinctly points out 'All life choices are contingent on the opportunities and constraints of social structure and culture' (p. 2). 
Educational stratification is not only imposed upon the student but also may be selfimposed. Research has indicated that students from similar class backgrounds may cluster around particular institution types and degree programs (Thomas and Quinn 2007). Evans (2009) points to the processes of 'self-limitation' (p. 348) in relation to female learners' choices around higher education; similarly, Reay et al. (2005) indicate that choice for their working-class participants was governed by conceptions of 'fit' with the institution. In the case of first-in-family students, such self-restriction can result in this group being more likely to 'study less prestigious subjects at less prestigious universities' (Spiegler and Bednarek 2013, p. 324).

The lack of knowledgeable 'other' also confines university choice and impacts upon individuals once they arrive at university. A previous study (O'Shea 2007) on first-infamily students reported a sense of bewilderment in the initial weeks caused by fundamental institutional processes, for example enrolment procedures, financial requirements and timetabling. The participants in this study reported feeling isolated and lonely, feelings that were exacerbated by uncertainty related to university language, expectations and protocols of behaviour. Such gaps in understanding can contribute to individuals having a 'lack of entitlement to be there, which may have a negative impact on [...] self-confidence' (Thomas and Quinn 2007, p. 77). The emotional facets of this move into higher education for first-in-family students cannot be overlooked; this is an embodied move, which can engender feelings of 'displacement, anxiety and guilt', alongside the more expected and anticipated emotions such as 'hopeful anticipation, pleasure and self-esteem' (Christie et al. 2008, p. 569).

According to US data, first-in-family students are also more likely to be of ethnic or migrant backgrounds; Chen (2005) reports that almost twice as many American first-infamily students are derived from black, Hispanic or other ethnic backgrounds. Within Australia, poorer educational outcomes and lower levels of intergenerational mobility are reported for students from low socio-economic backgrounds (OECD 2015). A significant number of financially disadvantaged students can also be assumed to be the first in their family to attend university so this attendance is further complicated by limited access to both fiscal and social capitals that support success.

The literature in this field indicates the various obstacles encountered by diverse student cohorts, providing some insight into why university may not be perceived as a possible, or even a welcome, opportunity. However, what is less clear is how cohorts such as first-infamily students manage this transition and enact success within this environment. The study outlined in this article sought to explore how such cohort navigated the higher education environment by drawing upon Yosso's Community Cultural Wealth framework. The following sections will provide details of these conceptual underpinnings before moving onto an overview of the study and presentation of findings.

\section{Conceptual framework}

Numerous studies in the field of educational inequality have drawn upon the work of Bourdieu and Passeron (1977) and Bourdieu (1986) exploring how educational systems can reproduce social inequality by exalting or enacting certain cultural practices associated with the dominant classes (Dumais and Ward 2009; Tramonte and Willms 2009, amongst others). According to Bourdieu (1986), capital can be economic or cultural, the latter defined by family or social position. There are different forms of cultural capital, often 
imbued within the taken-for-granted nature of certain knowledge forms and practices. Bourdieu (1986) identifies how this cultural capital is characterised by three states: objectified in tangible goods such as books and pictures, institutionalised as academic credentials or awards, and the embodied form which is characterised by 'long-lasting dispositions of the mind and body' (p. 243) which Bourdieu terms as habitus.

A student's habitus can limit their educational success as it can impact upon the ability to 'decode the implicit "rules of the game"' that they encounter (Aschaffenburg and Maas 1997, p. 573). Such a perspective identifies that students do not necessarily lack knowledge but rather that the knowledge or cultural capital that they hold may not be valued within the higher education environment. This is particularly the case for those students who have no tradition of Bourdieu's institutionalised cultural capital, such as those who are the first in their family to come to university. This cohort may lack the necessary cultural or knowledge capital required to negotiate the implicit nature of an institution's 'hidden curriculum'. Thus, the knowledge and expectations presumed within the class or lecture theatre may confirm certain groups whilst negating others.

However, Bourdieu has been critiqued for elevating the nature of structure in his theorisation and limiting the effects of agency, suggesting that individuals are constrained by structural forces largely beyond their control (Pitman 2013). In response to this and the need to decentre male, white privilege in understanding cultural capitals, Yosso (2005) challenges traditional interpretations of Bourdieu's work in order to better understand the intersection of student and institutional capital. Yosso's Community Cultural Wealth framework $(\mathrm{CCW})$ transforms the implicit deficit nature of Bourdieuian capital, foregrounding experiential knowledge in order to displace white middle-class culture as the 'standard' with '....all other forms and expressions of "culture" ... judged in comparison to this norm' (p. 76). Thus, CCW is not a critique of Bourdieu's work but rather serves to reclaim a concept that has been 'hijacked' as a means to legitimise dominant cultural practices. Yosso (2005) points out that understandings of cultural capital largely reflect what is valued by the dominant classes rather than being forms of knowledge that are inherently possessed by this class. There are other forms of cultural knowledge that are equally valued by more marginalised and less powerful groups as Yosso argues: 'Traditional Bourdieuian cultural capital theory...place[s] value on a very narrow range of assets and characteristics' (2005, p. 77).

The CCW framework draws upon an interdisciplinary knowledge base informed by migrant studies, critical race theory, sociology and gender studies. The diffuseness of this approach responds to the need to adapt diverse theoretical lenses in order to reconceptualise approaches to retaining and supporting students from diverse backgrounds. Yosso (2005) proposes six forms of cultural capital, indicated in the Fig. 1.

Yosso's categories include aspirational capital, which is an individual's ability to 'maintain hope and dreams for the future' despite 'real and perceived' obstacles (p. 77); this is a form of resilience and involves 'nurturing a culture of possibility' (p. 78). Resistance capital refers to the values and dispositions used to inform oppositional behaviours, a form of capital that nurtures attitudes that challenge status quo whilst linguistic capital recognises the strengths of communication skills including storytelling, bilingualism and the 'ability to communicate via visual art, music or poetry' (Yosso 2005, p. 79). Navigational capital is required to move effectively through social institutions and is premised upon both 'individual agency' and 'social networks' that negotiate educational and employment spaces, whereas social capital refers to networks that surround people providing both embodied and practical support. Finally, familial capital recognises those 


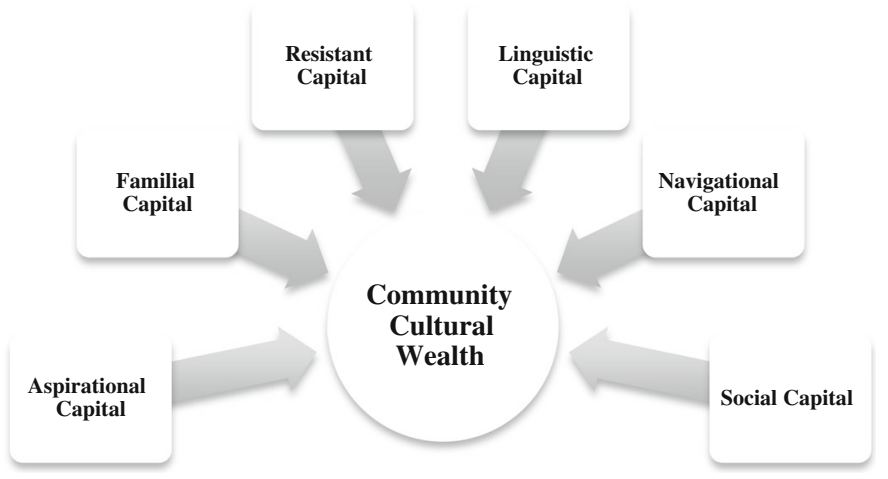

Fig. 1 Community Cultural Wealth framework (Yosso 2005)

'cultural knowledges nurtured among familial (kin)' (p. 79); this includes 'extended' family and friends.

Community Cultural Wealth has been theorised in relation to Hispanic students and Communities of Colour within the USA, the capitals that Yosso defines are not without cultural or ethnic specificity, but arguably this framework has broad considered application to other non-dominant and under-represented groups in society. The strength of Yosso's framework for this study was providing a solid means to interrogate data in terms of what first-in-family individuals bring to the university environment and how these types of capitals potentially enable them to enact success. Yosso's theory allowed me to think alongside the data, moving analysis away from a mechanistic process and instead negotiating connections between and within data and theory. However, given the cultural specifics of Yosso's theorisations, this is not intended to be an exact or neat application but rather provides a means for alternative ways of thinking about first-in-family student experience.

CCW is informed by Critical Race Theory which is 'committed to social justice, locating the voice of marginalized and employing the concept of intersectionality' (Ortiz and Jani 2010, p. 176). Drawing on CRT through the lens of CCW, this article attempts to deeply explore the 'voices' of one group of disadvantaged students, a cohort marginalised both educationally and financially. These participants were derived from a region that contains some of the most impoverished areas based on indicators related to social wellbeing, health, economic and education outcomes (Vinson et al. 2015). The following section provides a detailed overview of this region as well as providing demographic details of participants volunteered during interviews.

\section{Research context and design}

The study was conducted at a large campus $(n=24,099)$ of a regional university during 2013 and involved in-depth interviews with 23 students who identified as being first-infamily to attend university. The university is located in an area with comparably poorer educational outcomes and higher levels of unemployment. Traditionally, this region has relied on mining and manufacturing for employment, but in recent years, both sectors have faltered leading to higher rates of unemployment, $6.2 \%$ for the region compared to $5.2 \%$ 
nationally. Similarly, nearly $25 \%$ of couple families have neither partner working compared to $19 \%$ for the country as a whole (ABS 2011). Whilst there is no available data set on first-in-family students, the latest available statistics (2006) indicates that the total percentages of 25-34 year olds holding a degree in areas close to the university vary from 10 to $20 \%$, which is again lower than state $(22 \%)$ and national $(21 \%)$ figures.

In 2013, when this study took place, $14 \%$ of enroled students at this university were derived from low socio-economic backgrounds as defined by census collection districts and postcode indicators. ${ }^{1}$ Data on first-generation status rely on student self-disclosure on university enrolment forms, and whilst statistics are not released publically, the percentage of first-in-family domestic students who attend this university is approximated at $15 \%$ of the total population; this is both at the undergraduate and postgraduate levels.

The research was funded by a small university grant, and the focus was on domestic students in the first year of study who identified as being first-in-family on their enrolment form $(n=1500)$. The overall research objective of the study was to deeply explore the experiences of this cohort as they participated in university studies with particular reference to how this participation informed intergenerational choices around, and perceptions of, higher education amongst family and community.

A random sample of 800 students was sent an email invite to participate in the study, and a total of 63 students responded to the invite. Twenty-eight participants attended an interview, but five interviews were later eliminated because participants either revealed university attendance amongst other family members (3) or that they were undertaking a second degree (2). Interviews lasted an average of $50 \mathrm{~min}$ as students were encouraged to reflect upon experiences at length. Whilst this study is limited by size, context and location, the qualitative findings do explore this field in a deeply descriptive manner, and this study has informed further exploration of this field (O'Shea et al. 2015).

Each of the participants presented as Anglo Australian but as the interviews evolved a diversity of circumstances and backgrounds emerged. For example, five participants explicitly referred to 'working-class' or 'blue-collar' origins (Rose, Yvonne, Tina, Tom, and Eva), two described being of migrant descent (Sam and Helen) and two make direct reference to poverty within the family (Nigel and Natalie). A number were in receipt of social security payments or hardship scholarships (Alan, Elaine, Emma, Eva, Lena, Linda, Nancy, Natalie, and Yvonne); for those who had been previously employed most reported casual or unskilled work experiences. Table 1 highlights the broad demographic characteristics of the cohort, including a summary quote from each regarding 'getting to' university; these quotes further reveal the diversity of this cohort.

Interview transcripts were imported into NVivo (10), and line-by-line analysis was employed to identify initial codes and emerging thematic categories; a constant comparative method of analysis (Charmaz 2006) was utilised to examine concepts that inductively emerged from data. Undoubtedly, my positioning as a woman, a parent and a university staff member impacted upon what I 'saw' within the data. Rather than sideline these subjectivities, I adopted an ongoing and recursive form of 'bracketing' (Rolls and Relf 2006) engaging in regular reflection and memo writing whilst analysing these data. This act of writing enabled me to recursively engage with the data, checking implicit assumptions

\footnotetext{
1 Prior to 2010, socio-economic status (SES) was measured in relation to postcodes; low, medium and high SES status was calculated by Australian Bureau of Statistics data on factors such as income, educational attainment, employment status and dwelling types. Since 2010, this measurement has been refined by drawing on data within census collection districts, which are more narrowly comprised of 250 households in a common postcode.
} 
Table 1 Demographic details of research participants

\begin{tabular}{|c|c|c|c|c|c|c|}
\hline Name & Age & Children & Program & Status & $\begin{array}{l}\text { Prior } \\
\text { employment }\end{array}$ & $\begin{array}{l}\text { Summary quote on } \\
\text { 'getting to' university }\end{array}$ \\
\hline Alan & 42 & 2 & B Commerce & Married & Musician & $\begin{array}{l}\text { I sort of see where my } \\
\text { parents and family life } \\
\text { went and I knew that I } \\
\text { wasn't going to be able } \\
\text { to be a blue-collar } \\
\text { worker all my life and I } \\
\text { didn't want to be. } \\
\text { Some people are cut } \\
\text { out for that; some } \\
\text { people love that-for } \\
\text { me, no. I wanted to } \\
\text { start using my brain } \\
\text { instead of my brawn }\end{array}$ \\
\hline Emma & 19 & No & B Science & Single & School student & $\begin{array}{l}\text { A lot of them [family } \\
\text { members] didn't get } \\
\text { the chance to do this } \\
\text { sort of thing and have } \\
\text { so much support } \\
\text { through the university, } \\
\text { getting the scholarships } \\
\text { and all that sort of } \\
\text { thing }\end{array}$ \\
\hline Nigel & 26 & No & B Education & Single & $\begin{array}{l}\text { Casual retail } \\
\text { (shop) }\end{array}$ & $\begin{array}{l}\text {...that was just the society } \\
\text { that I'd grown up in. } \\
\text { University students } \\
\text { weren't all that } \\
\text { common }\end{array}$ \\
\hline Tina & 28 & No & B Science & Partnered & Navy personnel & $\begin{array}{l}\text {...you've got to optimise } \\
\text { your opportunity that } \\
\text { you are here- I feel } \\
\text { very lucky to be here }\end{array}$ \\
\hline Tom & 62 & No & B Commerce & Partnered & Hospitality & $\begin{array}{l}\text { Of course that's the } \\
\text { greatest deterrent-do } \\
\text { us oldies really want to } \\
\text { go into a classroom } \\
\text { with all these bright } \\
\text { and sparkly new kids } \\
\text { and have to play at } \\
\text { their level }\end{array}$ \\
\hline Helen & 19 & No & B Arts & Single & Student & $\begin{array}{l}\text {...they always ask me like } \\
\text { "What's it like there? } \\
\text { Are the people nice? } \\
\text { How are the academics } \\
\text { there?" I know one of } \\
\text { my brothers, his } \\
\text { interest is always } \\
\text { pegged for uni-he's } \\
\text { always wanted to do it } \\
\text { but it was sort of like } \\
\text { he's got a family and } \\
\text { he's got to care for } \\
\text { them so he can't really } \\
\text { fit it into his timetable }\end{array}$ \\
\hline
\end{tabular}


Table 1 continued

\begin{tabular}{|c|c|c|c|c|c|c|}
\hline Name & Age & Children & Program & Status & $\begin{array}{l}\text { Prior } \\
\text { employment }\end{array}$ & $\begin{array}{l}\text { Summary quote on } \\
\text { 'getting to' university }\end{array}$ \\
\hline Linda & 20 & No & B Arts & Single & Student & $\begin{array}{l}\text { [Uni] kind of been my } \\
\text { own selfish thing and to } \\
\text { show everyone that I'm } \\
\text { not what they say }\end{array}$ \\
\hline Tony & 22 & No & $\begin{array}{l}\text { B Health } \\
\text { Sciences }\end{array}$ & Single & $\begin{array}{l}\text { TAFE } \\
\text { student/casual } \\
\text { work }\end{array}$ & $\begin{array}{l}\text { [My family] don't really } \\
\text { have too much to say } \\
\text { about me going to } \\
\text { university other than } \\
\text { they assume that all } \\
\text { university students are } \\
\text { on drugs }\end{array}$ \\
\hline Carla & 22 & No & B Science & Single & $\begin{array}{l}\text { TAFE } \\
\text { student/casual } \\
\text { work }\end{array}$ & $\begin{array}{l}\text { High school wasn't } \\
\text { me...I've kept doing } \\
\text { dead end jobs-just } \\
\text { little bits there, little } \\
\text { bits there. I think it was } \\
\text { good that they're } \\
\text { [cousins and family] } \\
\text { seeing me now that I'm } \\
\text { actually doing } \\
\text { something with my life }\end{array}$ \\
\hline Nancy & 64 & No & B Commerce & Single & $\begin{array}{l}\text { Long-term } \\
\text { unemployed }\end{array}$ & $\begin{array}{l}\text { I never could, in my } \\
\text { younger days, get to } \\
\text { university because you } \\
\text { had to pay for it in our } \\
\text { time-it wasn't the } \\
\text { case that you could get } \\
\text { it for free }\end{array}$ \\
\hline Terry & 23 & No & B Engineering & Single & $\begin{array}{l}\text { Retail (hire } \\
\text { shop) }\end{array}$ & $\begin{array}{l}\text { I was just second- } \\
\text { guessing myself } \\
\text { coming here, whether it } \\
\text { was the right thing to } \\
\text { do or not just because } \\
\text { my marks weren't } \\
\text { really that great }\end{array}$ \\
\hline David & 32 & 1 & B Arts & Partnered $^{\mathrm{a}}$ & $\begin{array}{c}\text { Casual bank } \\
\text { employee }\end{array}$ & $\begin{array}{l}\text { I've always wanted to } \\
\text { come to university; I } \\
\text { know I've wanted to be } \\
\text { a teacher since I was } \\
15 \text { years old because } \\
\text { some of my teachers I } \\
\text { just have the utmost } \\
\text { respect for }\end{array}$ \\
\hline Kylie & 17 & No & B Science & Partnered & Student & $\begin{array}{l}\text { It was getting over what } \\
\text { everyone else had to } \\
\text { say to get here. } \\
\text { Everyone in my } \\
\text { family... I was kind of } \\
\text { the black sheep } \\
\text { because of my parents } \\
\text { so it was overcoming } \\
\text { what everyone else had } \\
\text { to say to be able to get } \\
\text { here }\end{array}$ \\
\hline
\end{tabular}


Table 1 continued

\begin{tabular}{|c|c|c|c|c|c|c|}
\hline Name & Age & Children & Program & Status & $\begin{array}{l}\text { Prior } \\
\text { employment }\end{array}$ & $\begin{array}{l}\text { Summary quote on } \\
\text { 'getting to' university }\end{array}$ \\
\hline Ann & 36 & 2 & B Science & Partnered & $\begin{array}{l}\text { Retail } \\
\quad \text { (supermarket) }\end{array}$ & $\begin{array}{l}\text { In some low income } \\
\text { families, it's something } \\
\text { that you're brought up } \\
\text { to just get out and go } \\
\text { get a job; you're not } \\
\text { brought up to go get a } \\
\text { higher education }\end{array}$ \\
\hline Elaine & 36 & 5 & B Commerce & $\begin{array}{l}\text { Single parent } \\
\text { (recently } \\
\text { repartnered) }\end{array}$ & $\begin{array}{l}\text { Office admin } \\
\text { (accounts) }\end{array}$ & $\begin{array}{l}\text { It was something that I } \\
\text { didn't really think } \\
\text { myself when I finished } \\
\text { high school; I finished } \\
\text { Year } 10 \text { and I didn't } \\
\text { think I could have gone } \\
\text { to uni; we never } \\
\text { discussed that plan. I } \\
\text { just went straight out to } \\
\text { work like my parents } \\
\text { did }\end{array}$ \\
\hline Eva & 48 & 2 & B Nursing & $\begin{array}{l}\text { Single parent } \\
\text { (widowed) }\end{array}$ & Cleaner & $\begin{array}{l}\text { [Uni] is prestigious, it is } \\
\text { selective and I always } \\
\text { know I'm proof of } \\
\text { that... hard work- } \\
\text { being selected because } \\
\text { of hard work }\end{array}$ \\
\hline Lena & 43 & 2 & B Arts & $\begin{array}{l}\text { Single parent } \\
\text { (divorced) }\end{array}$ & Shift worker & $\begin{array}{l}\text { When I was actually } \\
\text { growing up, a lot of } \\
\text { the-especially kids in } \\
\text { my area-it was } \\
\text { basically almost taught } \\
\text { that university was } \\
\text { only for those that were } \\
\text { really smart, extremely } \\
\text { smart... }\end{array}$ \\
\hline Natalie & 43 & 2 & B Arts & $\begin{array}{l}\text { Single parent } \\
\text { (divorced) }\end{array}$ & $\begin{array}{l}\text { Casual } \\
\text { employment } \\
\text { (bank/retail) }\end{array}$ & $\begin{array}{l}\text { We'll manage. I'll work. } \\
\text { I'll work and do full- } \\
\text { time uni. I will do it. If } \\
\text { I've got to do it I will } \\
\text { do it. I will drive } \\
\text { myself (laughing)-I } \\
\text { need to, I really need to }\end{array}$ \\
\hline Nina & 36 & 3 & B Arts & Partnered $^{\mathrm{a}}$ & Dental nurse & $\begin{array}{l}\text { I was raised in the } \\
\text { "University isn't for } \\
\text { people like us"- } \\
\text { they're mum's words. } \\
\text { My job is in the home } \\
\text { and that's where I } \\
\text { should be...I'm trying } \\
\text { to tell our kids that No, } \\
\text { you need to do this, } \\
\text { you'll want to do this; } \\
\text { there is a big, wide } \\
\text { world out there }\end{array}$ \\
\hline
\end{tabular}


Table 1 continued

\begin{tabular}{|c|c|c|c|c|c|c|}
\hline Name & Age & Children & Program & Status & $\begin{array}{l}\text { Prior } \\
\text { employment }\end{array}$ & $\begin{array}{l}\text { Summary quote on } \\
\text { 'getting to' university }\end{array}$ \\
\hline Rose & 28 & 2 & B Arts & Partnered & $\mathrm{P} / \mathrm{T}$ in retail & $\begin{array}{l}\text { I was like "Maybe I } \\
\text { shouldn't be here, } \\
\text { maybe I'm just a } \\
\text { fraud". I was like "Oh } \\
\text { my God"... My second } \\
\text { assignment. When I got } \\
\text { my marks back I think } \\
\text { that's when I was like } \\
\text { "Okay, I deserve to be } \\
\text { here just like anyone } \\
\text { else" and I finally just } \\
\text { went "Okay, you can } \\
\text { do this. It's all good" }\end{array}$ \\
\hline Sam & 44 & 2 & $\begin{array}{l}\text { B Arts- } \\
\text { Creative }\end{array}$ & Partnered $^{\mathrm{a}}$ & Tourism & $\begin{array}{l}\text { I wanted to learn but there } \\
\text { was also like a need for } \\
\text { me to become... not to } \\
\text { become smarter but } \\
\text { just to become more... } \\
\text { you know, just to have } \\
\text { that broadening of my } \\
\text { consciousness }\end{array}$ \\
\hline Sheila & 28 & 1 & B Arts & Partnered & Hairdresser & $\begin{array}{l}\text { I always knew when I was } \\
\text { younger-like when I } \\
\text { left school-“I'll go to } \\
\text { uni but I'm not ready to } \\
\text { go to university now". } \\
\text { I wasn't ready, I } \\
\text { wanted to travel and do } \\
\text { other things }\end{array}$ \\
\hline Yvonne & 45 & 2 & B Arts & Single parent & $\begin{array}{l}\text { Teaching } \\
\text { assistant }\end{array}$ & $\begin{array}{l}\text { My mum didn't have a } \\
\text { trade at all. So I think } \\
\text { really middle-class } \\
\text { families, they are all } \\
\text { for education and then } \\
\text { a lot of your working } \\
\text { class or poor, they } \\
\text { don't quite grasp the } \\
\text { importance of it }\end{array}$ \\
\hline
\end{tabular}

${ }^{a}$ Partner been to university

and destabilising assumed understandings. Interviews were open-ended to position the interviewees in the role of expert, providing the opportunity for experiences to be remembered in detailed 'storied moments' (Polkinghorne 1995, p. 11). The interview was guided by a series of broad topics as follows:

- Experiences of university as well as motivations around attending

- Reactions from friends and family

- Family members' perceptions of university attendance

- Experiences related to 'being' a university student 
Initial analysis revealed how participants drew upon a range of personal and familial resources to move into higher education and also survive in this environment. In order to further 'open-up' the data, the Community Cultural Wealth framework provided a powerful means to conceptualise how first-in-family students draw upon existing capitals and also how these capitals are used to enact educational success. The following section presents the findings with discussion, but focuses on three key capitals namely aspirational, resistant and familial capital, both navigational and social capitals also featured in analysis but are explored in other related publications (O'Shea 2014a, b). Linguistic capital was characterised by the ways parenting students used storytelling as a means to engage children in the university environment and will be explored in a future publication. However, there are also silences in Yosso's framework in relation to this particular cohort and so this discussion will also propose an additional capital termed 'experiential capital' that participants referred to during interviews.

\section{Discussion of findings}

For most of this cohort, commencing university was overwhelming, but this sense of the unknown and bewilderment was more pronounced for the older participants. Both Nina and Yvonne sum up the nature of these first impressions:

I had no idea - the first day I was here and I got lost and wandered around and I went home to my husband and said "There's a whole food hall there and a supermarket sort of thing and everything"...I wasn't expecting that. (Nina)

It feels like I'm in an institution that has a whole different language. (Yvonne).

For the students who had left school within a year of two of coming to university (Emma, Helen, Kylie), this transition was less traumatic. For example, Emma had come directly from school, and whilst she was the first in her family to attend, her reflections about commencing are very different to Nina and Yvonne's, her preparedness is very clear as she explained:

'Well I'd been to a couple of the "Into Uni" days and that sort of thing. I sort of not "fell in love" with the university but I was really, really happy with it and had good expectations when I came and they've been fulfilled so that's good' (Emma, 19). Whilst this research categorised participants in terms of being 'first-in-family', it is important to note that various social domains and identities intersected individuals. Experiences in higher education were shaped by a diversity of variables including (but not limited to) age, gender, social class and ethnicity. In recognising this intersectionality, this study moved away from one-dimensional constructions of first-in-family learners, which largely focus on perceptions of 'lack'. The narratives told in interviews indicated that whilst these firstin-family participants may not have an educational memory of higher education participation nor a family 'other' knowledgeable in academic practices, there are other more fundamental but equally rich personal resources drawn upon in this transition. To further analyse and explore the particular strengths of this cohort, Yosso's conceptualisations of aspirational, resistant and familial capitals were considered in relation to the emergent themes. 


\section{Aspirational capital}

Aspirational capital is a form of resilience which allows both the individual and their children to "dream of possibilities beyond their present circumstances, often without the objective means to attain those goals' (Yosso 2005, p. 78). As such, aspirational capital provides the basis for a culture of possibility, and during interviews, each participant displayed this capital in some way. This variously took the form of retaining the dream of attending university through to encouraging family members to consider university as a viable option.

Amongst older learners, there was a collective sense that attending university was a long-held ambition and also something for the self rather than others; this was particularly the case for the older women:

...uni is just me, it's just something else I've actually wanted to achieve. (Lena) ...I wanted to go uni for me so I got in. I was like "I'll start doing it for me"... (Rose)

I am older and I kind of know who I am and what I want and what I want to get out of this...I'm doing this for me. (Elaine)

Eva, a widower with two dependent children, explained how her motivation for coming to university was long-held, a dream that she had worked towards for many years. Eva's extended family was characterised by early disengagement from formal learning, her three sisters left high school with no qualifications, as did both parents. Eva characterised her family members as 'hard workers', but she was the only one to gain a final high school certificate. After school, university attendance was not an option for Eva: 'I had parents that didn't encourage any of that ... the general feeling is "You leave and you get a job"'. The death of her husband provided both a catalyst and motivator for her attendance but her immediate need to work and also parent two young children had led to a seven-year hiatus before applying to university. For Eva, gaining entrance to her degree was the achievement of a deeply held desire as she described:

I haven't breezed in here, I've really had to work hard ... there was no plan B for me, it had to be to come here and get this. (Eva)

Appadurai (2004) argues that the capacity to aspire is informed by 'navigational capacity', those who are more privileged have better access to resources that enable them to '...explore the future more frequently and more realistically' (p. 69). To enact future desired selves, it is necessary for individuals to have the opportunity to practice aspiration building and move beyond their 'brittle horizon of aspirations' (p. 69). The horizons for these students may have been somewhat 'brittle' but they are not without aspirations rather it has taken them a little longer to 'map a journey' (p. 76) to university. Seven participants explicitly stated that these aspirations had been confirmed since arriving, for example Linda, who was interviewed with her mother, described how prior to entering university all she had 'wanted was a job at $\mathrm{Myer}^{2}$...' but now:

Linda: Now I'm thinking about it, I can be an intern...

Natalie (Mum): You can do it all. You're under-selling yourself

Linda: Yes, I was kind of ripping myself off

${ }^{2}$ Myer is an Australian department store. 
Both Linda and Natalie were attending university simultaneously, but a range of financial and educational factors hampered this attendance. Linda had disengaged from formal education in her early teens, and her mother, a sole parent, had given up work to attend university. Both existed on government benefits and lived in state housing. Financial constraints were mentioned throughout the interview, only recently had they managed to gain an Internet connection due to a one-off hardship grant. When asked about reactions from others about their attendance, Natalie explained how '...it's been shock because they've constantly put us down into a category and boxed us into this little thing that we fit into because of housing, Centrelink [government benefit]...' However, rather than be thwarted by these attitudes, Natalie explained 'So that's a motivation too- "Stuff you all!"' Aspirations can be derived from a variety of sources and sometimes can be a reaction to perceived limitations, a form of what Yosso (2005) terms as 'resistant capital'.

\section{Resistant capital}

Resistant capital refers to knowledge and skills that have developed due to 'resistance to subordination' (Yosso 2005, p. 80), the specific focus of CCW being how people of colour resist racist messages and subordination. However, in the case of these participants, many of whom indicated being in receipt of state benefits or on low incomes, this capital is better conceptualised as a form of resistance to the status quo. This resistance was a powerful motivator for engaging and persevering in higher education. For the older female participants, this resistance was also related to prescribed gender roles and the need to do something for the 'self' rather than others. The transformative properties of attending university are particularly noted in the research conducted with female learners (O'Shea 2014a, b; Stone and O'Shea 2012), but the older female participants in this study also referred to their attendance in terms of resistance. University participation was regarded as an opportunity to resist constraints around what is deemed as possible, a refusal, perhaps, to be defined by Appadurai's 'brittle horizons'.

Ann, who had her first child at 19, described how she drew upon people's perceptions of her as a 'nobody' to provide the impetus to attend university '... because I was a young mum people obviously don't expect you to go out and achieve something at such a late part in life but I always knew that's what I wanted to do...'(Ann). Similarly, other participants reflected on how resistance to not only others but also limitations caused by employment or social class provided the means to persevere at university, as Lena explained: ' ... people ... said a few years ago: "You'll never go to university". Same when they'd turn around and say "You'll never own a house". Sorry, I'm at uni and I own a house.'

The interviews indicated how these students were not blank slates when they arrived at university but instead drew upon existing capital resources, applying these in innovative ways to support this transition. Both family and community, or what Yosso terms as familial capital, also complemented this personal agency, limiting the isolation of individuals by providing embodied support.

\section{Familial capital}

Research has pointed to the importance of developing social network within the university (Perry and Allard 2003; Spady 1970; Tinto 2002; Wilcox et al. 2005), but few studies explore how family networks impact upon first-in-family students. Much of this previous 
research reflects on the family as being a deficit to the student or as Gofen (2007) explains portraying first-in-family students 'as succeeding despite their family background' (author's emphasis, n/p). However, a small number of studies indicate how family and community support can assist educational success and retention, particularly for minority students. For example, Choi (2002) reports how for Korean Americans retaining close ties to family was a positive predictor for academic success. Drawing on almost a decade of research, Nora (2001-2002) argues that support from 'significant others' particularly family members cannot be overlooked in students' educational success.

Participants in this study similarly described how family assisted them to navigate and transition into this environment. Yvonne's sister whilst not able to advise on 'academic stuff or anything like that' provided necessary encouragement in difficult times:

Even at my darkest, darkest times that I've had last semester, she was always, "You know, you can actually do this..." (Yvonne)

Similarly, David's wife provides practical and emotional support: 'With my wife, I talk to her about everything; I think she reads my essays more than anyone'. Children, in particular, provided both motivation and also 'reassurance' that this choice was the right one. Rose described her children's reactions:

My older one ... he's always saying "I understand mum, you've got to go to uni so you can be a teacher"...My youngest, he sits up at the table "I'm doing uni work mum" and things like that.

Children provided both an impetus to return to higher education and also an encouragement to continue particularly with regard to future financial security. Alan described how with 'the kids [...] growing up...I came to the realisation that I'm never going to be rock star' and so enroled in a Commerce degree.

Participants also reflected upon how familial capital had been enriched because of this attendance. Parents of older children referred to new conversations about learning that were occurring; very different conversations to what they had experienced growing up. Ann had always considered university to be for others: 'people who are a lot smarter or have parents who have the money to put them through uni'. However, Ann's experiences at university were actively redefining her ambitions for her son:

I've been stretching his mind ... so he's really looking now at even becoming an interpreter, following a career path so he can go and travel...

Sam is also enriching family capital in home by redefining going to university as "natural and all very normal'. When asked why she is encouraging her children to attend university, she simply explained:

From what I'm getting out of university, just the pure sublime... that process of learning and that process of retaining information... it's empowering. (Sam)

Finally, themes related to age and experience also featured strongly in these narratives. The following section explores how prior experiences impacted upon higher education participation, indicating access to a form of 'experiential capital' for older participants. 


\section{Experiential capital}

The experiences encountered by the older and younger students obviously differed but interestingly perceptions of age and age appropriateness for study featured most strongly in the older students' narratives. Five of the older students described feeling a sense of stigma around their age. For example, Nigel at 26 revealed how he needed to 'play down' his age relying on the fact that he looked younger:

... they all thought that I was 19 or 20 or something which is great; they just accepted me immediately without that "Oh he's an older age student"... (Nigel)

Nancy explained how '...you're looking at a sea of kids which is fine and I think some of the old buggers would probably freak out on the first day going “Geez, I'm out of here, this is too much for me with all these kids"'. Yet, being more mature was also perceived as a strength for the older members of this group, Elaine described how ' ... I'm not just doing it because my employer's sent me to uni...I'm doing this for me'. This age difference provided her with the confidence to 'bounce off the teacher a bit more. The students that have just come from high school just sit there...'. Similarly, David described his younger self as someone who was 'social' and 'wouldn't get the work done' compared to: 'Now, I sit down, I plan out my assessments... I actually dedicate time to study', whilst Sheila outlined how her experiences as an apprentice hairdresser provided her with skills to deal with both staff and students at university.

The two eldest participants, Nancy (64) and Tom (62), defined a range of a priori knowledge that they applied to the environment. Tom argued that '...us oldies are well aware of [our] shortcomings. You don't get to our age without knowing what you're good at and what you're not good at.' For Nancy, her knowledge was both reassuring and distracting: '... what I've got to do is sit down and shut up because my problem is that I know the answers to the questions and I've got to let you kids answer the questions ...'. For older students, skills and knowledge they had acquired in their pre-student lives provided significant capital, which they drew upon. This experiential capital was a distinct strength for this group, providing skills in managing competing demands, dealing with difficult people (sometimes staff) and also maintaining resilience in often very trying circumstances. Additional analysis of the nature and application of this capital forms the focus of further research in this field (O'Shea et al. 2015).

\section{Conclusions and recommendations}

This study responds to Nunez's (2009) call for qualitative analysis of how students actually access and convert capital within the higher education environment, providing insight into the 'dynamics of capital conversion' (p. 42). In terms of aspirational capital, it was clear how participants drew upon both ambitions and desires for the future as a form of motivation. These participants are often the 'high achievers' of their social class (Gofen 2007), and having well-articulated aspirations provides not only an impetus to enrol but also a source of strength whilst persisting. Closely linked to these motivations was what Yosso terms as 'resistant capital', which was largely related to learners' experiences of social stratification. Key to these students' narratives was resistance to prescribed gender roles and also, status quo, particularly for female students and those stigmatised by poverty or social class. 
Research indicates that older women are most likely to experience guilt and anxiety around a move into higher education, particularly those with caring responsibilities. A number of authors have indicated how returning to education for women can challenge roles and positionality within the household (Brine and Waller 2004; George and Maguire 1998). For women, time for study is a gendered construct with an expectation that women will coordinate learning activities around household activities (Stone and O'Shea 2013). Whilst few studies have focussed solely on first-in-family women, broader research indicates the powerful changes learning can have on mothering identities (Giles 1990) and roles in the household (Stone and O'Shea 2012) leading, in some cases, to relationship breakdowns (Edwards 1993). We often underestimate the power of higher education institutions to be spaces, which can enable learners to engage with 'issues of power' (Pyne and Means 2013, p. 187). However, the narratives of these older female participants serve as a powerful reminder about how university attendance can provide an opportunity to rewrite life scripts and redefine prescribed gender roles in a powerfully liberating way.

Applying the lens of Yosso's familial capital to this study also revealed the very powerful influence that family had on learners. These participants described how their learning was both encouraged by others and also engendered knowledge acquisition within the household. University attendance provided a new capital as fresh discourses around learning emerged with the intergenerational impacts of these conversations heralding benefits for all. Parental workplace participation has measurable positive impacts on family members' emotional and financial well-being (Cassells et al. 2011) but how parental educational participation impacts upon family well-being is relatively unknown. These are the hidden or invisible outcomes from university attendance: conversations within the household and the passing of knowledge between family members.

Yosso's model has largely been applied to students from ethnic minorities, but this framework has much to offer research on broader under-represented groups in the university landscape. This study has used $\mathrm{CCW}$ as a lens to expose how assumptions around cultural wealth are based upon the values of dominant social groups rather than existing as neutral artifacts. However, this is not an unproblematic application, and there are some silences in Yosso's model, particularly how prior life experiences impact upon transition and engagement within this environment. Research on how first-in-family status intersects with a range of variables (including age and gender) in the production of cultural wealth is ongoing (O'Shea et al. 2015). The latter research includes interviews with significant others in students' lives to gain a more nuanced understanding of this intersectionality.

When students step into the university environment, the focus should be less on working upon the students to change or alter them in order to engender a 'sense of fit' with the institution. Rather, we need to rethink how we consider the notion of integration within higher education organisations. This reconceptualisation should consider the very strong capitals that learners arrive with, regardless of ethnicity, SES status or educational background. As this research has indicated, these students all arrived with a range of capitals, but the challenge for institutions is to work effectively with what learners have rather than expect them to change or disregard these strengths. Higher education policies and practices need to shift away from the manufacturing of 'sameness' (Bejarano and Valverde 2012) amongst new entrants.

Equally, it may be necessary to rethink institutional integration conceptually. As Nunez (2009) argues in relation to Latino students, effective integration may 'not represent a full commitment to the institution's mores...but, rather represent a distinctive sense of agency' (p. 42). For the students in this study, this 'sense of agency' is clearly situated in the narratives told around aspirational, resistant, familial and, in some cases, experiential 
capitals. Applying Yosso's framework to this Australian first-in-family cohort serves to reposition understanding of this group not as students 'without' but rather as individuals 'with'-this represents a significant shift in thinking within educational policy discourse both within Australia and beyond.

Acknowledgments This work was supported by a University of Wollongong Educational Strategies Development Grant (2013).

\section{References}

ABS. (2011). Census quickstats. http://www.censusdata.abs.gov.au

Appadurai, A. (2004). The capacity to aspire: Culture and the terms of recognition. In V. Rao \& M. Walton (Eds.), Culture and publication (pp. 59-84). Stanford, CA: Stanford University Press.

Aschaffenburg, K., \& Maas, I. (1997). Cultural and educational careers: The dynamics of social reproduction. American Sociological Review, 62(4), 573-587.

Ball, S., Davies, J., David, M., \& Reay, D. (2002). 'Classification' and 'Judgement': Social class and the 'cognitive structures' of choice of higher education. British Journal of Sociology of Education, 23(1), 51-72.

Bejarano, C., \& Valverde, M. (2012). From the fields to the university: Charting educational access and success for farmworker students using a Community Cultural Wealth framework. Association of Mexican-American Educators (AMAE) Journal, 6(2), 22-29.

Bourdieu, P. (1986). The forms of capital. In J. Richardson (Ed.), Handbook of theory and research for the sociology of education (pp. 241-257). New York: Greenwood Press.

Bourdieu, P., \& Passeron, J. C. (1977). Reproduction in education, society and culture. London: Sage Publications.

Brachman, C. (2012). Improving access and success for first-generation college students. America's Promise Bulletin. http://www.americaspromise.org

Brine, J., \& Waller, R. (2004). Working-class women on an access course: Risk, opportunity and (re)constructing identities. Gender and Education, 16(1), 97-113.

Bryan, E., \& Simmons, L. A. (2009). Family involvement: Impacts on post-secondary educational success for first-generation Appalachian college students. Journal of College Student Development, 4, 391-406.

Cassells, R., McNamara, J., Gong, H., \& Bicknell, S. (2011). Unequal opportunities: Life chances for children in the lucky country. Sydney: The Smith Family.

Charmaz, K. (2006). Constructing grounded theory: A practical guide through qualitative analysis. London: Sage Publications.

Chen, X. (2005). First generation students in postsecondary education: A look at their college transcripts (NCES 2005-171): National Center for Education Statistics. Washington, DC: US Government Printing Office.

Choi, K. (2002). Psychological separation-individuation and adjustment to college among Korean American students: The roles of collectivism and individualism. Journal of Counseling Psychology, 49(4), 468-475.

Christie, H., Tett, L., Cree, V. E., Hounsell, J., \& McCune, V. (2008). A real rollercoaster of confidence and emotions: Learning to be a university student. Studies in Higher Education, 33, 567-581.

Coates, H., \& Ransom, L. (2011) Dropout DNA, and the genetics of effective support. AUSSE Research Briefings, 11, 1-16. http://research.acer.edu.au/ausse/1/

Dumais, S. A., \& Ward, A. (2009). Cultural capital and first-generation college success. Poetics, 38, 245-265.

Edwards, R. (1993). Mature women students: Separating or connecting family and education. London: Taylor and Francis.

Elder, G. (1998). The life course as developmental theory. Child Development, 69(1), 1-12.

Evans, S. (2009). In a different place: Working class girls and higher education. Sociology, 43(2), 340-355.

Gardner, J. N. (1996). Helping America's first-generation college students. About Campus, 1, 31-32.

George, R., \& Maguire, M. (1998). Older women training to teach. Gender and Education, 10(4), 417-430.

Giles, J. (1990). Second chance, second self? Gender and Education, 2(3), 357-361.

Gofen, A. (2007). Family capital: How first-generation higher education students break the intergenerational cycle (pp. 1-33). Wisconsin-Madison: Institution for Research on Poverty. 
Ishitani, T. (2006). Studying attrition and degree completion behaviour among first generation college students in the United States. Journal of Higher Education, 77(5), 861-885.

Jackson, A., \& Mazzei, L. (2013). Thinking with theory in qualitative research: Viewing data across multiple perspectives. London: Routledge.

Nora, A. (2001-2002). The depiction of significant others in Tinto's "Rites of Passage": A reconceptualization of family and community in the persistence process. Journal of College Student Retention, 3(1), 41-56.

Nunez, A. (2009). Latino students' transition to college: A social and intercultural capital perspective. Harvard Educational Review, 79(1), 22-48.

O'Shea, S. (2007). Well I got here...but what happens next? Exploring the early narratives of first year female students who are the first in the family to attend university. Journal of Australian and New Zealand Student Services Association, 29, 36-51.

O'Shea, S. (2014a). Transitions and turning points: How first-in-family female students story their transition to university and student identity formation. International Journal of Qualitative Studies in Education, 27(2), 135-158.

O'Shea, S. (2014b). Filling up silences: First-in-family students, capital and university talk in the home. International Journal of Lifelong Education, 34(2), 139-155. doi:10.1080/02601370.2014.980342.

O'Shea, S., May, J., Stone, C. \& Delahunty, J. (2015). Breaking the barriers: Supporting and engaging firstin-family learners and their families. Final Project Report. http://firstinfamily.com.au

OECD. (2013). Education indicators in focus (September). http://www.oecd.org/education/skills-beyondschool

OECD. (2015). OECD employment outlook 2015. Paris: OECD Publishing. doi:10.1787/empl_outlook2015-en.

Ortiz, L., \& Jani, J. (2010). Critical race theory: A transformational model for teaching diversity. Journal of Social Work Education, 46(2), 175-193. doi:10.5175/JSWE.2010.200900070.

Pascarella, E., Pierson, C., Wolniak, G., \& Terenzini, P. (2004). First-generation college students: Additional evidence on college experiences and outcomes. The Journal of Higher Education, 75(3), 249-284.

Perry, C., \& Allard, A. (2003). Making the connections: Transition experiences for first-year education students. Journal of Educational Policy, 4(2), 74-89.

Pitman, T. (2013). Miraculous exceptions: What can autobiography tell us about why some disadvantaged students succeed in higher education? Higher Education Research \& Development, 32(1), 30-42. doi:10.1080/07294360.2012.750278.

Polkinghorne, D. E. (1995). Narrative configuration in qualitative analysis. International Journal of Qualitative Studies in Education, 8(1), 5-23.

Pyne, K., \& Means, D. (2013). Underrepresented and in/visible: A Hispanic first-generation student's narrative of college. Journal of Diversity in Higher Education, 6(3), 186-198.

Reay, D., Ball, S., \& David, M. (2005). Degrees of choice: Social class, race and gender in higher education. Chester: Trentham Books Limited.

Rolls, L., \& Relf, M. (2006). Bracketing interviews: Addressing methodological challenges in qualitative interviewing in bereavement and palliative care. Mortality, 11(3), 286-305.

Spady, W. (1970). Dropouts from higher education: An interdisciplinary review and synthesis. Interchange, $1,64-85$.

Spiegler, T., \& Bednarek, A. (2013). First-generation students: What we ask, what we know and what it means: An international review of the state of research. International Studies in Sociology of Education, 23(4), 318-337.

Stone, C., \& O'Shea, S. (2012). Transformations and self-discovery: Stories of women returning to education. Champagne, IL: Common Ground Publishing LLC.

Stone, C., \& O'Shea, S. (2013). Time, money, leisure and guilt: The gendered challenges of higher education for mature-age students. Australian Journal of Adult Learning, 53(1), 95-116.

Thayer, P. B. (2000). Retention of students from first generation and low-income backgrounds. Opportunity Outlook: The Journal of the Council for Opportunity in Education, 2-8.

Thomas, L., \& Quinn, J. (2007). First generation entry into higher education: An international study. Berkshire: SRHE and Open University Press.

Tinto, V. (2002). Establishing conditions for student success. Paper presented at the 11th Annual Conference of the European Access Network. Monash University, Prato.

Tramonte, L., \& Willms, J. D. (2009). Cultural capital and its effects on education outcomes. Economics of Education Review, 29, 200-213.

Vinson, T., Rawsthorne, M., Beavis, A., \& Ericson, M. (2015). Dropping off the edge 2015. www.dote.org. au 
Waterman, S. J., \& Lindley, L. S. (2013). Cultural strengths to persevere: Native American women in higher education. NASPA: Journal about Women in Higher Education, 6(2), 139-165.

Wilcox, P., Winn, S., \& Fyvie-Gauld, M. (2005). It was nothing to do with the university, it was just the people: The role of social support in the first-year experience of higher education. Studies in Higher Education, 30(6), 707-722.

Yosso, T. (2005). Whose culture has capital? A critical race theory discussion of Community Cultural Wealth. Race Ethnicity and Education, 8(1), 69-91. 